\title{
Indigenous health and nursing in Roraima in the 1970s
}

\author{
Saúde indígena e enfermagem em Roraima na década de 1970 \\ Salud de los indígenas y enfermería en Roraima en la década de 1970
}

Raphael Florindo Amorim 1,"1
ORCID: 0000-0002-7491-4257

Jacquelaine Alves Machado " ORCID: 0000-0002-5523-6876

Keythluci Faria Trigueiro da Silva " ORCID: 0000-0002-2475-7388

Fernando Porto " ORCID: 0000-0002-2880-724X

'Universidade Federal de Roraima. Boa Vista, Roraima, Brazil. "Universidade Federal do Estado do Rio de Janeiro. Rio de Janeiro, Rio de Janeiro, Brazil.

How to cite this article: Amorim RF, Machado JA, Silva KFT, Porto F. Indigenous health and nursing in Roraima in the 1970s. Rev Bras Enferm. 2019;72(4):848-53. doi: http://dx.doi.org/10.1590/0034-7167-2017-0791

Corresponding Author Raphael Florindo Amorim E-mail: raphael.amorim@ufrr.br

Submission: 11-10-2017 Approval: 02-27-2019

\begin{abstract}
Objective: To analyze the strategies undertaken by the government to address the health problem in Boa Vista/Roraima. Method: A study using the microhistory approach, with documentary sources from journalistic material of the 1970s through the triangulation technique: texts, images and context, with analysis from the perspective of the Social World Theory. Results: It was evidenced that the strategies undertaken by the government occurred in favor of the exploration of isolated areas in Roraima that demanded settlement processes, construction of villages and a highway to enable the interconnection of the state with other regions of Brazil, with a smoke screen symbolic effect produced by nurses on indigenous health. Conclusion: There was governmental manipulation, when the symbolic power was unveiled, making it possible to see and believe that nursing needs to guide political issues rather than being ruled.
\end{abstract}

Descriptors: Nursing; Health of Indigenous Peoples; History of Nursing; Nurse; Health.

\section{RESUMO}

Objetivo: Analisar as estratégias empreendidas pelo governo para sanar o problema da saúde em Boa Vista/Roraima. Método: Estudo na abordagem da micro-história, com fontes documentais oriundas de matéria jornalística da década de 1970, quando foram articulados, por meio da técnica de triangulação, textos, imagens e contexto, com análise na perspectiva da Teoria do Mundo Social. Resultados: Foi evidenciado que as estratégias empreendidas oriundas do governo ocorreram em prol da exploração de áreas isoladas em Roraima que demandaram processos de povoamento, construção de vilarejos e de uma rodovia para viabilizar a interligação do estado com demais regiões do Brasil, tendo por cortina de fumaça o efeito simbólico produzido pelas enfermeiras na saúde indígena. Conclusão: Houve manipulação governamental, quando o poder simbólico foi desvelado, fazendo ver e crer que a enfermagem precisa pautar os assuntos políticos ao invés de ser pautada.

Descritores: Enfermagem; Saúde Indígena; História da Enfermagem; Enfermeira; Saúde.

\section{RESUMEN}

Objetivo: Analizar las estrategias emprendidas por el gobierno para sanar el problema de la salud en Boa Vista / Roraima. Método: En el estudio de la micro-historia, con fuentes documentales oriundas de materia periodística de la década de 1970, cuando fueron articulados, por medio de la técnica de triangulación, textos, imágenes y contexto, con análisis en la perspectiva de la Teoría del Mundo Social. Resultados: Se evidenció que las estrategias emprendidas oriundas del gobierno ocurrieron en pro de la exploración de áreas aisladas en Roraima que demandaron procesos de poblamiento, construcción de aldeas y de una carretera para viabilizar la interconexión del estado con otras regiones de Brasil, teniendo por cortina de humo el efecto simbólico producido por las enfermeras en la salud indígena. Conclusión: Hubo manipulación gubernamental, cuando el poder simbólico fue desvelado, haciendo ver y creer que la enfermería necesita pautar los asuntos políticos en vez de ser pautada.

Descriptores: Enfermería; Salud Indígena; Historia de la Enfermería; Enfermera; Salud. 


\section{INTRODUCTION}

Roraima is located in the Northern Region of Brazil, west of the Greenwich Meridian and is cut by the Equator, being the most northerly state of the Brazilian federation. It has 1,922 kilometers of border with South American countries, with Venezuela to the north and north-west and the Cooperative Republic of Guyana to the east, limited to the states of Amazonas to the south and west, and Pará to the southeast ${ }^{(1)}$.

The 1970s were marked by the context of the military dictatorship with expansion of the state infrastructure, with the opening of the BR-174 highway linking Boa Vista-RR to Manaus-AM, passing through the Waimiri-Atroari indigenous reserve.

We point out that the BR-174 is currently known as Manaus-Boa Vista. It is a longitudinal highway that connects Roraima and Amazonas to Venezuela, totaling 974 kilometers, marking the cities of Manaus and Pacaraima, with the completion of construction in 1998, under the government of Fernando Henrique Cardoso.

In 1973, the President of the Republic Emílio Garrastazu Medici sanctioned Law 6,001/1973. It regulated the legal situation of the Indigenous people and their communities, with the purpose of preserving their culture and integrating them progressively and harmoniously into national communion. Two years later, the Statute for the Association of Indigenous Defense (ADIBRA) was created, with the purpose of promoting cultural and assistance activities, in order to contribute to the referral of the indigenous problem ${ }^{(2)}$ and in the following two years the BR-174 was inaugurated, having throughout the section of colonization projects.

The consequence for the socio-economic and political development of the government in Roraima was inevitable. Among them, the imbalance of the health-disease process of the indigenous people, which led to the death of many of them. In this perspective, we have the participation of the nurses called by the government, in order to operationalize the process of care for the Indigenous, taking into account the intentions of the government in favor of the political interests of the time.

In summary, in the wake of the events we present as a problematizing aspect the situation in which the government interested in advancing to the countryside, triggered a series of actions of expropriation, invasion and deforestation in indigenous lands to attend to the enterprises said necessary for the development of the State, which at the time caused several health problems to the indigenous population.

The study is justified in order to broaden the discussion on the subject of indigenous health, as well as to understand how the politicians at the time used their actions strategies to promote the development of their state.

\section{OBJECTIVE}

To analyze the strategies undertaken by the government to address the health problem in Boa Vista/Roraima.

\section{METHOD}

\section{Ethical aspects}

The research used journalistic materials, thus respecting Law $9.610 / 1998$, on copyright in its current aspects ${ }^{(3)}$. Resolution
466/2012-CNS/MS does not apply in this study because it is an investigation with journalistic sources and does not directly involve human beings.

\section{Theoretical-methodological framework}

The theorization of results was based on the notions of sociologist Pierre Bourdieu.

\section{Type of study}

It is a study in the historical perspective, with the approach of the microhistory based on the documentary analysis.

\section{Data sources}

The documentary sources were two images published in the Jornal Boa Vista, referring to the years 1973 and 1974, as well as literature of adherence in the History of Brazil, Roraima, Health and Nursing.

\section{Data collection and analysis}

The sources of analysis were collected in the archives of the Official Press Office of the State of Roraima, when it was decided to search for news in the Boa Vista Newspaper, because it was the first and only newspaper to circulate continuously from 1973 to 1983 during the military dictatorship. The Official Press Office of the Federal Territory of Roraima created in 1973, through the Governor Lieutenant Colonel Hélio da Costa Campos, in his second term (1972 - 1974), thus founding the "Boa Vista" newspaper owned by the Government. purpose of publicizing the development, integration and security of the acts of the Federal Government to the citizens of the Territory ${ }^{(4)}$.

The search for the news resulted in two images, with the health topic as a criterion articulated the construction of the BR-174 highway in Boa Vista. By applying the criteria, the journalistic material was organized in the temporal sense, to circumstance them, as well as were submitted to the rules of criticism of authenticity credibility, internal and external. The purpose of these was to group the materials provided by the documentary sources and to analyze the aspects related to the content of the documents, in the sense of seeking information, through the triangulation of the data for the construction of the historical narrative $e^{(5)}$.

\section{RESULTS}

The first journalistic article, dated 11/12/1973, presents the actions of the Rondon Project in showing the performance of students from the health field, from the Federal University of Santa Maria (UFSM), in Rio Grande do Sul, parallel to the construction of the highway BR-174, and the second one, dated November 10,1974 , shows the readers of Roraima's nurses and secretary of health at a meeting due to the health problems of the population living in countryside in isolated and difficult to reach areas.

In summary, the communities mentioned in the journalistic material were formed by small farmers and prospectors from the 
most different regions of the country. They were attracted by the extraction of minerals, in addition to the indigenous population already existing in the region, when a discourse was identified to meet the demand for improvement and prevention in the health field due to the agglutination of people.

\section{DISCUSSION}

In the 1970s, in the context of dictatorship, the military arrived to occupy the Amazon region and with it the opening of roads through the North Perimeter. In order to do so, they used human resources to deforest the forest, when tractors and trucks passed through indigenous lands, and among the several consequences the death of hundreds of Yanomami Indians due to contact with the measles microorganism ${ }^{(6)}$.

In this scenario, the 10th FUNAI Regional Police Station in Roraima established Agrovila for indigenous tribes integrated into society ${ }^{(7)}$. At the time, the families received a lot of 50 hectares for cultivation. In addition, large-scale oil and gold extraction took place in the regions of Tapajós, Serra Pelada and Roraima ${ }^{(8)}$, which potentiated the agglutination of people in those lands, but with low health conditions.

In an arid scenario with simple dwellings, with thatched roofs and without adequate pavement for the surroundings, the government brings to the population Voluntary Units donated by the Rural Worker Assistance Fund (FUNRURAL). The scene was recorded in the Jornal Boa Vista, when it is possible to visualize the vehicle at the center of the photographic text and around the team's performance with the residents.

The text showed in the Figure 1 of the journalistic material, portrays the health care of the population with laboratory tests and the application of medications made available by the Medicines Center (CEME). The care team consisted of senior trainees from the Biomedical Sciences Courses: Nursing, Pharmacy, Biochemistry, Medicine and Dentistry, from the Federal University of Santa Maria, Rio Grande do Sul state, when they enrolled in the Rondon Project.

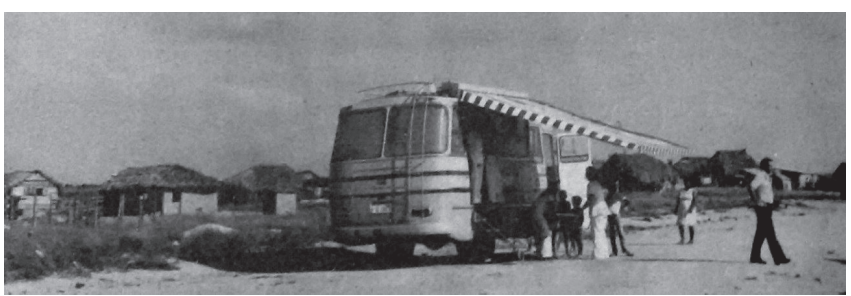

Source: Jornal Boa Vista 1973 dez 11; ano l, ed. 2 p. $6^{(9)}$

Figure 1 - Mobile Unit - attends the neighborhoods

The Federal University of Santa Maria, created in 1960, had the bachelors training courses ${ }^{(9-10)}$, who through the Rondon Project, developed health actions in the state of Roraima. This implied a field of practice and at the same time showed society what future professionals could do to the benefit of the population.

It should be noted that health services provided by the indigenous population were taken over by the National Indigenous Foundation (FUNAI), linked to the Ministry of Justice since 1967, by flying health teams, in the form of the Air Health Units Service (SUSA). These were responsible for the planning and execution of health actions in indigenous areas. The teams were composed of nursing assistants and technicians who provided occasional service $^{(11)}$. In fact, having the indigenous protection agency aligned with justice was a strategy that showed security to the health of the population, but also a government guarantee intervention in favor of their interests that aimed at opening roads.

The articulation of the policy to open roads, in Roraima, with a rearguard of action of the teaching in the health field, is to understand if it is a symbolic alliance ${ }^{(12)}$, to reach the interest of the state and federal politicians. To do so, this should be seen with one of the most good political intentions towards the population to provide better health conditions.

The symbolic alliance to attend to the effect, counted on the discourse that it became necessary to populate distant areas and of difficult access of the State of Roraima, consequently, in the governmental logic if would have the progress and development, especially with the opening of the road. Based on this argument, the government strategy was promoted and developed by the State, when the efficiency produced was shown; on the other hand, the population, in contact with the natives, led to unavoidable health problems.

In order to have a certain idea of the aggravations to indigenous health, $13 \%$ of the Yanomami population in the 1970 s died of measles and respiratory infections ${ }^{(13)}$. In order to try to alleviate the situation, meetings were held with the purpose of integrating health professionals, with the purpose of assisting the population in countryside of the State, where the indigenous populations inhabited.

The habitus of the local population had as its social effect ${ }^{(14)}$ the biological unbalance, in the body of the human being, when they were afflicted by health problems. This was caused by the production of established practice, in the name of "progress and development" that the context pointed out. So far, we can deduce that the official discourse was to attend to the culture of the care of the population, especially of the natives, but it lacked relevant considerations of the population habitus by imposing the reality of the dominant group.

Figure 2 shows the political strategy, when there was articulation of the secretary of health and the nurses responsible for the health services due to the social effect occurred. At the time, once again the press did not miss the opportunity to record the moment, when it registered in journalistic matters - text and image - the sense of ratifying government action.

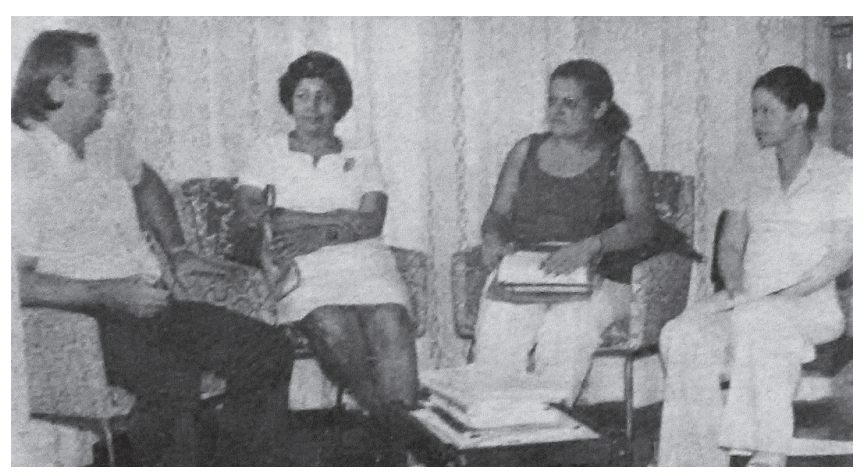

Source: Jornal de Boa Vista 1974 nov 10; ano I, ed. 11, p.4(15)

Figure 2 - Integrated Health Action 
In the Figure 2, it is possible to identify that people are organized in means to the attributes of landscapes, such as: chairs, table in the center with several documents on it and a curtain in the background. The photographic arrangement of the people portrayed - from left to right, we see Dr. Walter Bianchini - state health secretary, coordinators of health teams to control actions, nurses Florinda Molina, Pan American Health Organization (PAHO); Yolanda Chalfun, of Boa Vista Maternity and; Cleusa de Lourdes Longhi, from the immunization branch of the health department.

Of those portrayed, we highlight nurses Florinda Molina and Cleusa de Lourdes Longhi ${ }^{(16)}$, wearing their uniforms. This means understanding in the symbolic field, when it is possible to identify from where they spoke. Therefore, it is to understand the belief in the formatting of the capital framework and the symbolic effect of what it was capable of producing beyond words, but to consider the authorized aesthetics of the picture ${ }^{(12)}$.

Another highlight in the figure is the body's hexis portrayed, with focus on the lower limbs. The secretary of health is with lower limbs open; while the nurses with them crossed or closed. The corporal reading indicates that, as a public person, can show its power, in the representation of the phallus (in) visible, socially; unlike them, need to hide/protect in the confinement of the body ${ }^{(12)}$. This is male domination in one of its aspects, when it is shown in the body by the habitus inculcated to the feminine and masculine, meaning who dominates and determines what must and must happen ${ }^{(12)}$. In addition, the body incorporates these social relations, modeling them by the body hexis, which reflects in the postures, dispositions and relations of the body, inducing its way of thinking, acting and feeling in the social world ${ }^{(16)}$.

The nurses portrayed would constitute two pillars of support for the strategic plan to be developed by the government - maternal-child care and public health, articulated with PAHO. They were operative agents of government policy, in progress, which showed special attention to women and children, in combating/ preventing diseases with medicalization and immunization, especially for indigenous people.

The appreciation of women's work, on the one hand, was understood as operational, since they would be in charge of the secretary's supervision. This implies that they would be placed in second strategic line of decision making. On the other hand, as nurses and executors, they would act on the operational level of politics, which allowed them to accumulate cultural capital, even if supervised by a man. Therefore, in this understanding they did not govern government interests, but rather, they were based on the fact that the rules of the game were established, when each had its place - dominant/secretary of health and dominated/the nurses.

The interests of the dominant were the expansion of the state of Roraima to lands not yet exploited and manipulated by the political and economic power of the time. This is due to the innumerable possibilities of exploration promoted by the Amazon region, which aroused the greed of the most different segments of society, as well as the construction of a highway and to publicize the concern, seen as a visibility strategy to establish the belief. Therefore, when this type of strategy occurred, they were possibly manipulated ${ }^{(12)}$, because when they were called, they would participate in the interests at stake by the instituted symbolic power.
The symbolic power is like a magic that acts on the other by the habitus of the agents ${ }^{(12)}$. In this situation, the nurses for the journalistic material would intermediate the symbolic gains for the dominant ones. This implied in meeting the governmental interests, when by the sensitization to the cause, since supervised by the secretary of health - Dr. Walter Bianchini.

Nurses, when supervised, would have to adhere to the strategies to operationalize maternal and child health and public health actions that imbedded with public health. These priority understandings to the feminine, full of representation with the practices to be valued, to produce the symbolic effect expected by the dominant.

The strategy inculcated by the dominant was to establish the symbolic exchange ${ }^{(12)}$. In other words, calling them as health intervention actions in the region. Thus, they valued women's practices through nursing and made the population aware of the concern for health and, with this, they were able to advance in the achievement of projects that represented the interests of the State.

As it turned out, the politicians in the newspaper were concerned about their attitudes. However, unspoken was the expected effect beyond the health field, which we understand to be the construction of settlements in isolated areas, construction of the BR-174 highway (one of the main developments of the period), as well as other Government, whose execution depended on the exploitation of the areas occupied by indigenous peoples.

We know that the purpose of the construction of BR-174 was to connect Boa Vista/Roraima to Manaus/Amazônia, but also to the rest of the country, since traffic was precarious in the southern part of Roraima, when air traffic was predominantly, presented severe restrictions in need of development. At the time, in the midst of the context, a peacekeeping operation was organized, considering that the natives in defending their lands attacked government officials, for example. The conflicts reduced from two thousand to six hundred Indigenous, from those lands ${ }^{(17)}$.

The concern of the politicians and responsible for the natives was the insertion and maintenance of a town in Roraimense territory by the speech. This was understood as a strategy of condescension $^{(18)}$, when the words and attitudes pointed to one action, but the intention would have been different, causing the dominant to place the belief of what is established in the production of meaning.

The production of attributed meaning, we understand that there was concern of the politicians and responsible for the natives in meeting the demands of the health of that population. However, discourse is not actions, but intentions of its materiality and this is part of the attitudes of the dominant under the dominated, showing that it was obvious to meet that need, which ratifies the "false consciousness"(19). This implied in thinking that the responsible ones for the Indigenous began to compose the set of the dominant ones, which was understood inversely in the analysis, in the understanding that, they were submitted to them by the governmental interests.

\section{Study limitations}

The limitation of the study in the scope of the topic, considering the broad context of the 1970s, limited geographically in the state of Roraima, was like to analyze the sea, through the sample of its drop under the microscope, to identify what occurred in the macro micro when articulating the construction of the highway 
and the said of concern with health, which as a limitation, also, is refined with the approach used in the study of microhistory.

Another limitation is that the documents analyzed came from the government print media. This means if it is journalistic version. Therefore, it is a caveat that when they publish their stories, they direct the readers to see what they are interested in, in order to (in) form an opinion on the subject addressed ${ }^{(20)}$.

\section{Contributions to the area of nursing}

The study contributes to the understanding of the path from micro to macro pubic policies directed to indigenous health, currently based in the various fields, such as health, education, public administration, anthropology and history. On the other hand, we understand that the contribution may have been small in depth, but relevant to the awakening of versions and interpretations of events and events that occurred in the past, which draws attention to the present.

\section{FINAL CONSIDERATIONS}

The government with the strategy to build a highway in the region, as well as exploration of sparsely populated areas, used actions in the field of health as a smoke screen to achieve its objectives. The field of health was the way and the nurses were the agents of the smoke curtain to establish the belief.

The reading of the assertion for some may be understood as hasty, but one can understand what it is to be agenda and to be ruled. This implies when there is governmental interest in nursing, when one thinks of saying that we are the protagonists of the actions, which in reality are agents that help the interests at stake.

Understanding how actions and manipulations occur is to stay tuned to the interests that are at stake. In this, the value actions are important, but at the same time they are manipulated by the symbolic power that cover them.

Finally, assertions were made as academic provocations so that indigenous health, in the field of these policies, can be (re) thought as agenda, but carried out by Nursing.

\section{PROMOTION / ACKNOWLEDGMENT}

Universidade Federal do Estado do Rio de Janeiro - UNIRIO; and Universidade Federal de Roraima - UFRR.

Our gratitude to the servers of the archive of the Official Press of the State of Roraima.

\section{REFERENCES}

1. Freitas A. Estudos Sociais - Roraima: geografia e história. São Paulo: Corprint Gráfica e Editora; 1998.83 p.

2. Estatuto para Associação Indígena. Jornal Boa Vista (RR). 1974 Mar 12: p.5 Ano II (col. 1).

3. Presidência da República (BR), Casa Civil, Subchefia para Assuntos Jurídicos. Lei n. 9.610, de 19 de fevereiro de 1998. Altera, atualiza e consolida a legislação sobre direitos [Internet]. Diário Oficial da União: República Federativa do Brasil; 1998 [cited 2019 Mar 12 ] Feb 20. Seção 1: [about 14 screens]. Available from: http://www.planalto.gov.br/Ccivil_03/leis/L9610.htm

4. Andrade AJM. O jornal Boa Vista: porta-voz dos projetos desenvolvidos no Território de Roraima no período de 1973 a 1979. Boa Vista (RR): Universidade Federal de Roraima, Centro de Ciências Humanas, Coordenação do Curso de História; 2016.104 p.

5. Porto F, Fernandes GF, González JS. Fontes históricas e ético-legais: possibilidades e inovações. Cult Cuid [Internet]. 2009 [cited 2019 Mar 12];25:43-53. Available from: https://doi.org/10.14198/cuid.2009.25.07

6. Almeida A. Davi Kopenawa contra a 'Xawara' [Interview]. El País Brasil. 2014 Dez 28 [cited 2019 Mar 12]. Available from: http://brasil.elpais. com/brasil/2014/12/26/politica/1419618934_407302.html

7. FUNAI vai criar agrovila para Índio aculturado. Jornal Boa Vista (RR). 1973 Sept 22: p.8 Ano I (col. 1).

8. Santos NPD. Políticas públicas, economia e poder: o Estado de Roraima entre 1970 e 2000. [Thesis] [Internet]. Belém: Universidade Federal do Pará, Núcleo de Altos Estudos Amazônicos; 2004 [cited 2019 Mar 12]. 271 p. Available from: https://www.bc.ufrr.br\%2Findex.php\%2Fteses-e-dissertacoes\%3Fdownload\%3D398\%3Apolitic as-publicas-economia-e-poder-o-estado-de-roraima-entre-1970-e-2000\&usg=AOvVaw1ATpTLCPPnoh44Fnu61dGN

9. Unidade Volante - atende aos bairros. Jornal Boa Vista (RR). 1973 Dez 11: p.6 Ano I (col.1).

10. Saúde Pública terá impulso no decorrer deste ano - Resultado de 1974. Jornal Boa Vista (RR). 1975 Jan 19: p.4-5 Ano II (col. 2).

11. Ministério da Saúde (BR). Fundação Nacional de Saúde-FUNASA. Portaria n. 254 de 31 de janeiro de 2002. Aprovar a Política Nacional de Atenção à Saúde dos Povos Indígenas [Internet]. Diário Oficial da União: República Federativa do Brasil; 2002 [cited 2019 Mar 12]. 06 Feb. Seção 1: [about 18 screens]. Available from: http://www.funasa.gov.br/site/wp-content/files_mf/Pm_254_2002.pdf

12. Bourdieu P. Coisas ditas. São Paulo: Brasiliense; 2004. 116 p.

13. Bruce A. Urihi A: a terra-floresta Yanomami. São Paulo: Instituto Socioambiental; 2009.95 p.

14. Bourdieu P. Razões Práticas: sobre a teoria da ação. Campinas: Papirus; 1996. 223 p.

15. Ação integrada de saúde. Jornal Boa Vista - Suplemento Especial (RR). 1974 Nov 10: p. 4 Ano I (col. 1).

16. Bourdieu P. Esboço de uma teoria da prática. In: Ortiz R editor. Pierre Bourdieu. São Paulo: Ática; 1994. p.46-81.

17. Rodrigues EP, Pinheiro ES. O desflorestamento ao longo da rodovia BR 174 (Manaus/AM- Boa Vista/RR). Uberlândia-MG, 2011. Soc Nat [Internet]. 2011 [cited 2019 Mar 12];23(3):513-28. Available from: http://dx.doi.org/10.1590/S1982-45132011000300011 
18. García FV. Pierre Bourdieu: la sociología como crítica de la razión. Barcelona: Montesinos; 2002. 252 p.

19. Bourdieu P. O poder simbólico. Tomaz F, (Trad.). Rio de Janeiro: Bertrand Brasil; 1989. 307 p.

20. Bourdieu P. Sobre a televisão. Rio de Janeiro: Jorge Zahar; 1997. 144 p. 